\title{
Functional Modification of the Plasmid RP1-specified Pilus by Caulobacter vibrioides
}

\author{
By TA-CHIH HUA, DAVID R. SCHOLL AND JOSEPH D. JOLLICK* \\ Department of Zoology \& Microbiology and The College of Osteopathic Medicine, \\ Ohio University, Athens, Ohio 45701, U.S.A.
}

(Received 25 July 1980; revised 13 October 1980)

Caulobacter strains which contain plasmid RP1 are resistant to carbenicillin, kanamycin and tetracycline and can serve as donors of the plasmid, but such $\mathrm{R}^{+}$strains are not susceptible to the RP1-specific phage PRR1. Since both conjugation and phage PRR1 infection are mediated by the plasmid-specified pilus, the lack of phage binding suggests some functional alteration of the pilus. In this report we demonstrate that RP1 pili are produced by Caulobacter $\mathrm{R}^{+}$cells, but unlike the RP1 pili produced by PRR1-susceptible strains, the Caulobacter $\mathrm{R}^{+}$pili do not inactivate phage PRR1. Antibody produced against Caulobacter $\mathrm{R}^{+}$pili prevents phage PRR1 binding to RP1 pili from PRR1-susceptible strains of Pseudomonas aeruginosa and Escherichia coli, and also inhibits plasmid transfer by those strains. Antibody produced against RP1 pili from $P$. aeruginosa and $E$. coli inhibits plasmid transfer both by those strains and by Caulobacter $\mathrm{R}^{+}$donors. Phage PRR 1 rendered non-infectious by RNAase treatment prevents plasmid transfer by $P$. aeruginosa and $E$. coli but not by Caulobacter.

\section{IN TRODUCTION}

Although plasmids have not been reported to occur naturally in the differentiating bacterium Caulobacter, several plasmids have been introduced into organisms of this genus. Alexander \& Jollick (1977) demonstrated the transfer of plasmid RP1 to Caulobacter crescentus WS12 and Caulobacter vibrioides CV6. Ely (1979) subsequently transferred plasmids RP4, RK2, R702, R68.45 and R46 to several auxotrophic derivatives of $C$. crescentus CB15.

In their study of RP1 expression in Caulobacter, Alexander \& Jollick (1977) found that although the Caulobacter $\mathrm{R}^{+}$strains expressed the three RP1-specified antibiotic resistance markers (kanamycin, tetracycline and carbenicillin), these strains did not become susceptible to the plasmid-dependent phages PRD1 or PRR1 (as determined by a spot test using high titre phage lysates or by plaque formation using lower titre phage suspensions). In contrast, the RP4-containing Caulobacter strains of Ely (1979) were susceptible to high titres of those phages by the spot test but neither PRD1 nor PRR 1 formed plaques on his strains.

Plasmid RP1 is apparently intact in Caulobacter $\mathrm{R}^{+}$strains, since the strains can serve as donors of the plasmid, which when transferred to Escherichia coli or Pseudomonas aeruginosa is fully expressed including susceptibility to PRR 1 and PRD1. Since plasmid RP1 specifies a new pilus which has been shown to be the phage PRR 1 receptor organelle (Olsen \& Thomas, 1973) and is considered also to be the organelle of conjugation, the fact that Caulobacter $\mathrm{R}^{+}$strains can serve as effective donors of the plasmid yet remain insensitive to the plasmid pilus-specific phage PRR1 suggested the following possibilities: (1) Caulobacter $\mathrm{R}^{+}$strains do not produce RP1-specified pili and plasmid transfer by Caulobacter involves a pre-existing structure, e.g. common pili; (2) R P1 codes for two kinds of pili and Caulobacter 
$\mathrm{R}^{+}$strains produce the conjugal pilus but not the phage-binding pilus; or (3) RP1 codes for a single pilus type which serves both functions but in Caulobacter $\mathrm{R}^{+}$strains the pilus is modified so that it serves only the conjugal function, and cannot bind phage PRR 1 . In this report we present evidence which supports the third possibility.

\section{METHODS}

Organisms. The bacterial strains used are listed in Table 1. RNA phage PRR 1 and DNA phage PRD1 were obtained from Professor R. J. Olsen, Department of Microbiology, University of Michigan, Ann Arbor, U.S.A.

Chemicals and media. Chemicals and antibiotics were obtained from Sigma. Bacterial media were from either Difco or BBL. RNAase A was purchased from Worthington Biochemical Corp.

The complete medium for the growth of Caulobacter vibrioides WS48 was the peptone yeast extract (PYE) medium of Poindexter (1964). The complete medium for the growth of Pseudomonas aeruginosa PAO67, Escherichia coli CSH29 and Yersinia enterocolitica W277 was either nutrient medium, trypticase soy medium or TGE medium (Olsen \& Shipley, 1973). Phage PRR1 or PRD1 was propagated on TGE agar by the agar overlay method of Adams (1959).

The chemically defined (minimal) medium for the growth of prototrophic Caulobacter strains was described by Jollick \& Tran (1975). The minimal medium for the growth of $Y$. enterocolitica W277 was the same as that for the Caulobacter strains, but with the addition of $5 \mu \mathrm{g}$ thiamin $\mathrm{ml}^{-1}$ and $0.5 \mathrm{mg}$ sodium citrate $\mathrm{ml}^{-1}$. For the selective growth of auxotrophic E. coli CSH29, the minimal medium was supplemented with $10 \mu \mathrm{g}$ tryptophan $\mathrm{ml}^{-1}$ and $5 \mu \mathrm{g}$ thiamin $\mathrm{ml}^{-1}$. The selective medium for $\mathrm{R}^{+}$strains was the appropriate minimal medium with the minimal inhibitory concentration of carbenicillin, tetracycline or kanamycin.

Mating procedures. Donor and recipient cell titres were adjusted to approximately $3 \times 10^{8}$ colony-forming units (c.f.u.) $\mathrm{ml}^{-1}$, mixed at a ratio of $1: 1$ or $1: 10$ and then incubated at the optimum growth temperature of the recipient $\left(30^{\circ} \mathrm{C}\right.$ for C. vibrioides WS48 and Y. enterocolitica W277 and $37^{\circ} \mathrm{C}$ for E. coli CSH29) for $3 \mathrm{~h}$. The mating mixture was then diluted and plated on the appropriate selective medium. Transconjugant colonies were counted after 48 h when $E$. coli CSH29 or $Y$. enterocolitica W277 was the recipient, and after 1 week when $C$. vibrioides WS48 was the recipient.

Phage susceptibility test. Bacterial strains were tested for phage susceptibility by the agar layer method of Adams (1959) and by the routine test dilution (RTD) procedure of Blair \& Williams (1961). Nutrient agar was used as the base layer for phage susceptibility tests. In all cases $0.2 \mathrm{ml}$ of a $24 \mathrm{~h}$ broth culture of the bacterial strain to be tested was added to $4.0 \mathrm{ml}$ of molten soft $(0.6 \%, \mathrm{w} / \mathrm{v})$ agar kept at $46^{\circ} \mathrm{C}$. The molten agar was poured on to the base layer and allowed to harden, and then single drops $(0.01 \mathrm{ml})$ of serial 10 -fold dilutions of phage suspension containing about $10^{9}$ plaque-forming units (p.f.u.) $\mathrm{ml}^{-1}$ were placed on the surface. The plates were incubated at the appropriate temperature and examined after 24 and $96 \mathrm{~h}$.

Assay of unadsorbed phage PRR1. The absorbance of an $18 \mathrm{~h}$ broth culture of bacteria was adjusted to $A_{420}=$ 0.045 . which corresponds to a cell concentration of about $10^{8} \mathrm{cells}^{-1}$. Phage PRR 1 at a multiplicity of infection of 0.1 was added to the culture. The sample was mixed thoroughly and incubated for $10 \mathrm{~min}$ at $37^{\circ} \mathrm{C}$ for strain $\mathrm{CSH} 29$, or at $30^{\circ} \mathrm{C}$ for strain WS48. At the end of the incubation a $0.1 \mathrm{ml}$ sample was removed, diluted $1: 100$ in cold PYE medium, mixed gently, and filtered through a $0.45 \mu \mathrm{m}$ Millipore filter. The filtrate was diluted and $0.1 \mathrm{ml}$ of each dilution was added to $4 \mathrm{ml}$ of soft agar with $0.2 \mathrm{ml}$ of an $18 \mathrm{~h}$ broth culture of the indicator strain PAO67, and then plated. Unadsorbed phage was expressed as the percentage of input phage that remained infectious.

Table 1. Bacterial strains

Strain

Caulobacter vibrioides WS48

Escherichia coli $\mathrm{CSH} 29$

Yersinia enterocolitica W277

Pseudomonas aeruginosa PAO67
Characteristics

Prototroph, PRR $1^{\mathrm{r}}$, PRD $1^{\mathrm{r}}$

Trp $^{-}, \mathrm{B}_{1}^{-}$, PRR $^{\mathrm{r}}$, PRD $1^{\mathrm{r}}$

Prototroph, PRR $1^{r}$, PRD I ${ }^{r}$

$\mathrm{His}^{-}, \mathrm{FP}^{-}, \mathrm{PRR}^{\mathrm{s}}$, PRD $1^{\mathrm{s}}, \mathrm{Car}^{\mathrm{r}}, \mathrm{Tet}^{\mathrm{r}}, \mathrm{Kan}^{\mathrm{r}}(\mathrm{RP} 1)$
Source

Authors

Cold Spring Harbor

R. Hodinka

R. Olsen

Derivatives of WS48, CSH29 and W277 containing plasmid RP1 (indicated in the text by the suffix $\mathrm{R}^{+}$) are all resistant to carbenicillin (Car), tetracycline (Tet) and kanamycin (Kan). In addition, $\mathrm{CSH}_{2} 9 \mathrm{R}^{+}$and $\mathrm{W} 277 \mathrm{R}^{+}$ are susceptible to the plasmid-dependent phages PRR1 and PRD1, whereas WS48R ${ }^{+}$is not. Plasmid RP1 is maintained in PAO67, and all references to PAO67 in this report mean PAO67R ${ }^{+}$. 
Phage PRR1 titre increase experiment. PYE broth cultures of strains WS48 and WS48 ${ }^{+}$were adjusted to about $10^{8}$ c.f.u. $\mathrm{ml}^{-1}$. A $7 \mathrm{ml}$ portion of the cell suspension was mixed thoroughly with $1.0 \mathrm{ml}$ of a suspension of phage PRR $1\left(5 \times 10^{2}\right.$ p.f.u. $\left.\mathrm{ml}^{-1}\right)$ and $0.11 \mathrm{ml}$ of the mixture was added to each of 72 tubes containing $0.9 \mathrm{ml}$ of PYE medium. The tubes were incubated overnight at $30^{\circ} \mathrm{C}$. Then $3 \mathrm{ml}$ of soft agar and $0.2 \mathrm{ml}$ of PAO67 culture were added to each tube and the mixtures were plated on nutrient agar plates. Plaques were counted after $15 \mathrm{~h}$ incubation at $37^{\circ} \mathrm{C}$.

Phage inactivation by sheared surface appendages (shearates). Caulobacter strains were grown on PYE agar plates for $48 \mathrm{~h}$ and $E$. coli strains and PAO67 were grown on TGE agar plates for $24 \mathrm{~h}$. Plates for $\mathrm{R}^{+}$cells were supplemented with antibiotics inhibitory to $\mathrm{R}^{-}$cells. Cells were harvested by scraping the surface growth into $100 \mathrm{ml}$ of appropriate broth. The cells were then collected by centrifugation, using a GSA rotor, for $15 \mathrm{~min}$ at 8000 rev. $\mathrm{min}^{-1}$. Each cell pellet (about $2 \mathrm{~g}$ wet wt) was resuspended in $15 \mathrm{ml}$ of sterile distilled water and the cell surface appendages (pili and flagella) were removed by blending in a Waring blender for $60 \mathrm{~s}$ at low speed. The cells were pelleted again in an SS34 rotor for $15 \mathrm{~min}$ at $12000 \mathrm{rev} . \mathrm{min}^{-1}$. The supernatant (referred to as the shearate) was then exposed to u.v. light for $10 \mathrm{~min}$, with agitation. At the end of irradiation, $0.9 \mathrm{ml}$ of shearate was added to each of 14 tubes containing $0.1 \mathrm{ml}$ of a suspension of phage PRR1 (about $1.6 \times 10^{2}$ p.f.u. $\mathrm{ml}^{-1}$ ) and $10 \mu \mathrm{g}$ chloramphenicol. The shearate/phage suspension was incubated for $30 \mathrm{~min}$ at $37^{\circ} \mathrm{C}$. Then $3 \mathrm{ml}$ of soft agar and $0.2 \mathrm{ml}$ of PAO67 culture were added to each tube and the mixtures were plated on nutrient agar plates. Plaques were counted after $15 \mathrm{~h}$ incubation at $37^{\circ} \mathrm{C}$.

Effect of Caulobacter $R^{+}$supernatant on phage adsorption of other $R^{+}$shearates. Broth cultures of strains WS48R ${ }^{+}, \mathrm{CSH}_{29 \mathrm{R}^{+}}$and PAO67 were centrifuged, using a GSA rotor, at 8000 rev. $\mathrm{min}^{-1}$ for 10 min and the supernatants were filtered. Strains CSH29R ${ }^{+}$and PAO67 were grown on TGE agar plates and the cells were scraped off and resuspended in the filtered supernatants. After $1 \mathrm{~h}$ incubation, the cells were centrifuged, resuspended in $15 \mathrm{ml}$ of sterile distilled water and sheared in a Waring blender. The mixture was centrifuged, using an SS34 rotor, for $15 \mathrm{~min}$ at $12000 \mathrm{rev} \cdot \mathrm{min}^{-1}$ at $4{ }^{\circ} \mathrm{C}$. The shearate was dialysed against $12 \mathrm{l}$ of distilled water for $48 \mathrm{~h}$. A $0.9 \mathrm{ml}$ portion of the shearate and $0.1 \mathrm{ml}$ of a suspension of phage PRR $1\left(5 \times 10^{3} \mathrm{p} . \mathrm{f}\right.$.u. $\left.\mathrm{ml}^{-1}\right)$ were then mixed gently and incubated at $37^{\circ} \mathrm{C}$ for $1 \mathrm{~h}$. Then $4 \mathrm{ml}$ of soft agar and $0.2 \mathrm{ml}$ of PAO67 culture were added and the mixture was plated on nutrient agar plates. Plaques were counted after $15 \mathrm{~h}$ incubation at $37^{\circ} \mathrm{C}$.

Anti-shearate antiserum preparation. Lyophilized shearates were dissolved in sterile saline to a concentration of $1 \mathrm{mg} \mathrm{ml}^{-1}$. Equal volumes of the shearate/saline solution and Freund's complete adjuvant were homogenized. Rabbits (each weighing about $2.3 \mathrm{~kg}$ ) were bled for pre-immune serum, and then inoculated weekly by the following schedule: 1st week, $2 \mathrm{ml}$ antigen intraperitoneally; 2nd week, a total of $2 \mathrm{ml}$ subcutaneously (four locations); 3 rd week, resting; 4th week, a total of $2 \mathrm{ml}$ subcutaneously (four locations). On the 5 th week, serum was collected and stored at $-18^{\circ} \mathrm{C}$. The presence of antibodies against shearate components was demonstrated by Ouchterlony's double diffusion method (Ouchterlony, 1968).

Effect of anti-shearate antiserum on phage adsorption to whole cells. Bacteria were grown to approximately $10^{8}$ c.f.u. $\mathrm{ml}^{-1}$ in broth and $1 \mathrm{ml}$ of the culture was mixed with $1 \mathrm{ml}$ of antiserum and chilled for $10 \mathrm{~min}$. A $0.01 \mathrm{ml}$ portion of phage PRR 1 suspension (about $9 \times 10^{7}$ p.f.u. $\mathrm{ml}^{-1}$ ) was added to the mixture which was then placed in the cold for another $10 \mathrm{~min}$. A $1 \mathrm{ml}$ portion of this mixture was added to $99 \mathrm{ml}$ of chilled PYE broth and mixed by gentle inversion. The suspension was filtered through a $0.45 \mu \mathrm{m}$ Millipore filter. Then $0.1 \mathrm{ml}$ of the filtrate and $0.2 \mathrm{ml}$ of PAO67 culture were added to $4 \mathrm{ml}$ of molten soft agar and the mixture was plated on nutrient agar plates. Plaques were counted after $15 \mathrm{~h}$ incubation at $37^{\circ} \mathrm{C}$.

Phage inactivation by shearates in the presence of antiserum. Portions of $0.1 \mathrm{ml}$ each of shearate and antiserum were mixed and kept at room temperature for $10 \mathrm{~min} ; 0.1 \mathrm{ml}$ of a suspension of phage PRR1 (about $3 \times 10^{3}$ p.f.u. $\mathrm{ml}^{-1}$ ) was then added. The tubes were kept at room temperature for an additional $10 \mathrm{~min}$ before $4 \mathrm{ml}$ of soft agar and $0.2 \mathrm{ml}$ of PAO67 culture were added to each tube and the mixtures were plated on nutrient agar plates. Plaques were counted after $15 \mathrm{~h}$ incubation at $37^{\circ} \mathrm{C}$.

Bacterial conjugation in the presence of antiserum. The plasmid RP1-containing strains PAO67, CSH29R $\mathrm{R}^{+}$and WS48R ${ }^{+}$were used as donors in matings with $Y$. enterocolitica W277 as the recipient. Prior to mating, the donor cell titres were adjusted to approximately $10^{7}$ c.f.u. $\mathrm{ml}^{-1}$ and the recipient cell titres to approximately $10^{8}$ c.f.u. $\mathrm{ml}^{-1}$. A $0.5 \mathrm{ml}$ portion of the suspension of donor cells was first mixed with an equal volume of antiserum and incubated for $10 \mathrm{~min}$ at the appropriate temperature, and then $1 \mathrm{ml}$ of the recipient culture was added. The mating mixture was incubated for $3 \mathrm{~h}$ at $30^{\circ} \mathrm{C}$ and then plated on selective agar plates.

Bacterial conjugation in the presence of phage PRR1. Phage PRR1 $\left(3.8 \times 10^{10}\right.$ p.f.u. $\left.\mathrm{ml}^{-1}\right)$ was mixed with RNAase $A$ to give a concentration of $1 \mathrm{mg}$ RNAase $\mathrm{ml}^{-1}$. RNAase renders PRR 1 non-infectious only after adsorption and release of phage RNA. Strains PAO67 and WS48R ${ }^{+}$were chosen as donors and W277 as the recipient. Equal volumes $(0.5 \mathrm{ml})$ of the donor culture and the PRR1/RNAase preparation were first mixed and kept at room temperature for $15 \mathrm{~min}$, then $0.5 \mathrm{ml}$ of the recipient culture was added. The mating mixture was directly plated on selective agar plates.

Electron microscopy. Bacterial shearates and bacteriophage were examined using a Siemens Elmiskop I electron microscope. Specimens were negatively stained with $2.0 \%(\mathrm{w} / \mathrm{v})$ uranyl acetate. 
RESULTS

Adsorption of phage PRR1. Adsorption of phage PRR1 to all $\mathrm{R}^{+}$transcipients was determined. Pseudomonas aeruginosa PAO67, the donor strain that was used for the propagation of phage PRR 1, was also used as a positive control. Caulobacter vibrioides WS48 and E. coli CSH29 were used as negative controls. The results, expressed as the percentage of input phage adsorbed, showed that $P$. aeruginosa PAO67 cells adsorbed $22 \%$ of input phage and $E$. coli $\mathrm{CSH}_{2} 9 \mathrm{R}^{+}$cells adsorbed $28 \%$, whereas $C$. vibrioides $\mathrm{WS}^{2} 8 \mathrm{R}^{+}$ cells and the two negative controls adsorbed less than $5 \%$ of input phage.

Phage PRRI titre increase. The titre increase experiment is more sensitive than the standard phage susceptibility spot test in detecting minimal phage replication in apparently non-productive hosts. Plasmid RP1-containing Caulobacter strains showed no apparent susceptibility to phage PRR 1 as determined by the standard phage susceptibility tests. To determine whether low levels of phage PRR 1 were being produced by strain WS48R ${ }^{+}$, phage titre increase experiments were done. The total phage input in these experiments was about 7 p.f.u. per tube. The average number of plaques from 72 tubes of WS48/PRR 1 was $4 \cdot 11$ p.f.u. per plate, with a range of 0 to 18 . The average number of plaques from WS $48 R^{+} /$PRR 1 was 4.07 p.f.u. per plate, with a range of 0 to 13 . Statistical analysis of variance showed no significant difference $(P<0.05)$ in phage productivity between WS48 and WS48R $\mathrm{R}^{+}$.

Phage inactivation by various shearates. Shearates generated from $\mathrm{R}^{+}$and $\mathrm{R}^{-}$strains were examined by electron microscopy. Strain WS48 shearates contained two different cellular appendages: flagella about $20 \mathrm{~nm}$ in diameter and common pili about $5 \mathrm{~nm}$ in diameter (Fig. $1 a)$. Strain $\mathrm{WS}_{48 \mathrm{R}^{+}}$shearates, in addition to flagella and common pili, contained an appendage about $10 \mathrm{~nm}$ in diameter (Fig. $1 \mathrm{~b}, c$ ). An identical $10 \mathrm{~nm}$ diameter appendage was also seen in $\mathrm{CSH} 29 \mathrm{R}^{+}$shearates. When $\mathrm{CSH}_{2} 9 \mathrm{R}^{+}$shearate was incubated at room temperature with phage PRR1, binding of the phage to the $10 \mathrm{~nm}$ appendage confirmed that it was the R pilus (Fig. 2). Specific binding of phage PRR 1 to R pili in WS48R ${ }^{+}$shearates could not be seen by electron microscopy.

Shearates generated from PAO67 and $\mathrm{CSH}_{2} 9 \mathrm{R}^{+}$showed significant phage adsorption, PAO67 shearate adsorbing $30 \%$ of input phage PRR 1 and $\mathrm{CSH}_{2} 9 \mathrm{R}^{+}$shearate adsorbing $50 \%$. Shearates from CSH29, WS 48 or $\mathrm{WS}_{48 \mathrm{R}^{+}}$showed little or no phage adsorption (Table 2). Thus, although the RP1-specific pili were present in $\mathrm{WS}_{48} \mathrm{R}^{+}$shearates, they did not adsorb phage PRR1.

Effect of Caulobacter $W S 48 R^{+}$supernatant on phage adsorption of other $R^{+}$shearates. This experiment was designed to examine the possibility that WS48R $\mathrm{R}^{+}$produced an extracellular substance which might modify the RP1 pilus phage-attachment site so that the pilus could not function in phage adsorption, as seen in Caulobacter $\mathrm{R}^{+}$. With a phage PRR 1 input of 520 p.f.u. per plate, PAO67 shearate showed about $28 \%$ phage inactivation regardless of whether the cells were pre-incubated in Caulobacter WS48R ${ }^{+}$supernatant or the original PAO67 culture supernatant. $\mathrm{CSH}_{29 \mathrm{R}^{+}}$shearate showed about $46 \%$ phage inactivation regardless of whether the cells were pre-incubated in WS48R ${ }^{+}$supernatant or the original $\mathrm{CSH} 29 \mathrm{R}^{+}$supernatant. Thus, extracellular alteration of the phage adsorption pilus by a product of Caulobacter $\mathrm{R}^{+}$could not be detected.

Anti-shearate antiserum preparation. The presence of antibodies against shearate antigens was demonstrated by Ouchterlony's immunodiffusion method. Lines of identity of precipitation were detected between PAO67 shearate and anti-PAO67 and anti-CSH29R ${ }^{+}$ shearate antiserum. Lines of identity were also seen between $\mathrm{CSH}_{2} 2 \mathrm{R}^{+}$shearate and anti-CSH29R $\mathrm{R}^{+}$and anti-PAO67 shearate antiserum as well as between WS48 $\mathrm{R}^{+}$shearate and anti-PAO67 and anti-CSH29R ${ }^{+}$shearate antiserum. The immunodiffusion tests were used only to confirm that common plasmid-specified antigens were present in the shearates of the various $\mathbf{R}^{+}$strains. We did not identify the specific antigens. Cross-reactivity among the $\mathbf{R}^{-}$ strains was not seen. 

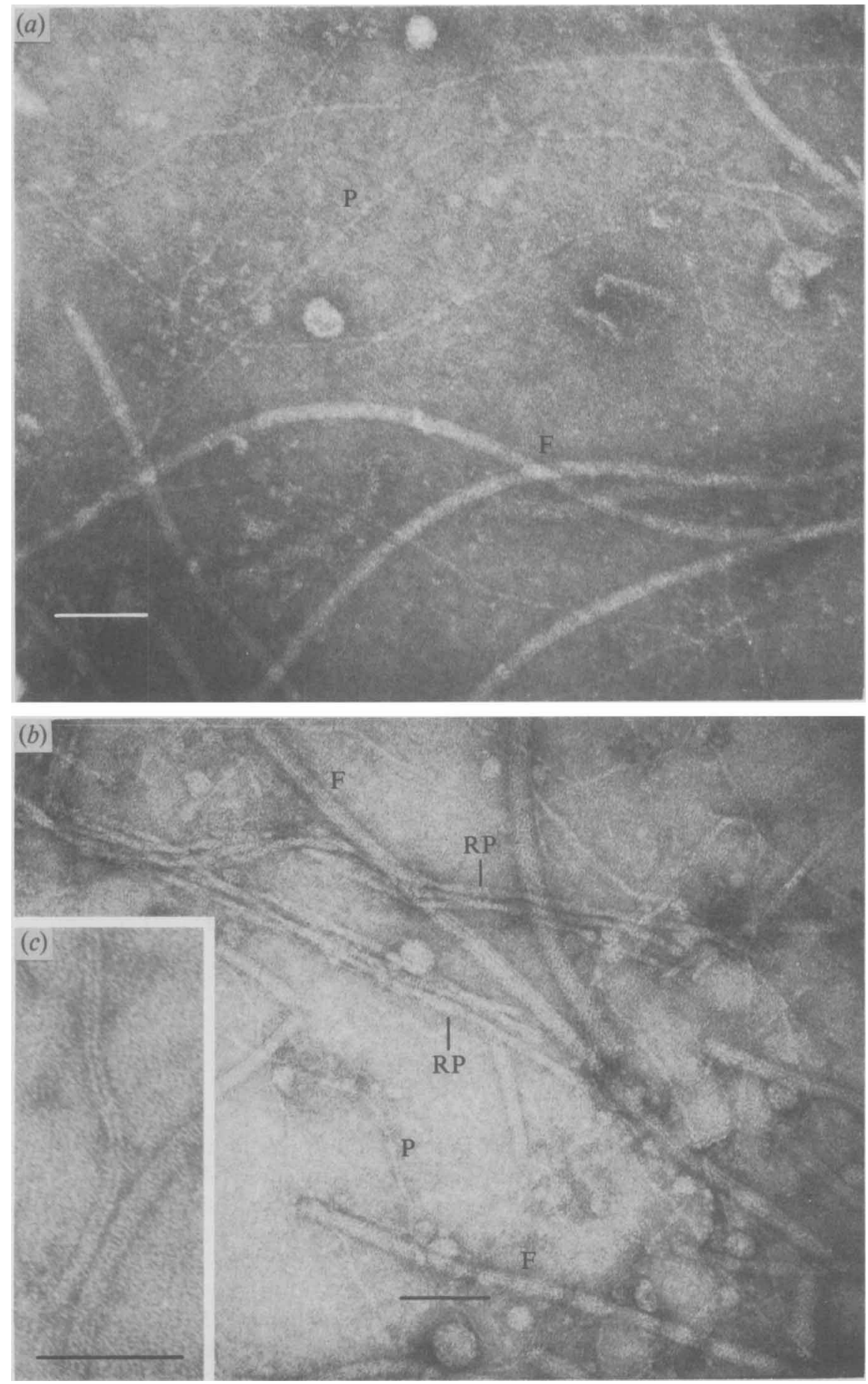

Fig. 1. Electron micrographs of shearates from $C$. vibrioides WS48 (a) and the isogenic RP1-containing transconjugant WS48 $\mathrm{R}^{+}(b)$. Note the presence of flagella $(F)$ and common pili (P) in both preparations while a third filament of approximately $10 \mathrm{~nm}$ diameter, the RP1-specified pilus (RP), is seen only in the shearate of the RP1-containing strain. The inset $(c)$ shows, at higher magnification, a C. vibrioides flagellum (right) and the RP1-specified pilus. The bar markers represent $100 \mathrm{~nm}$. 


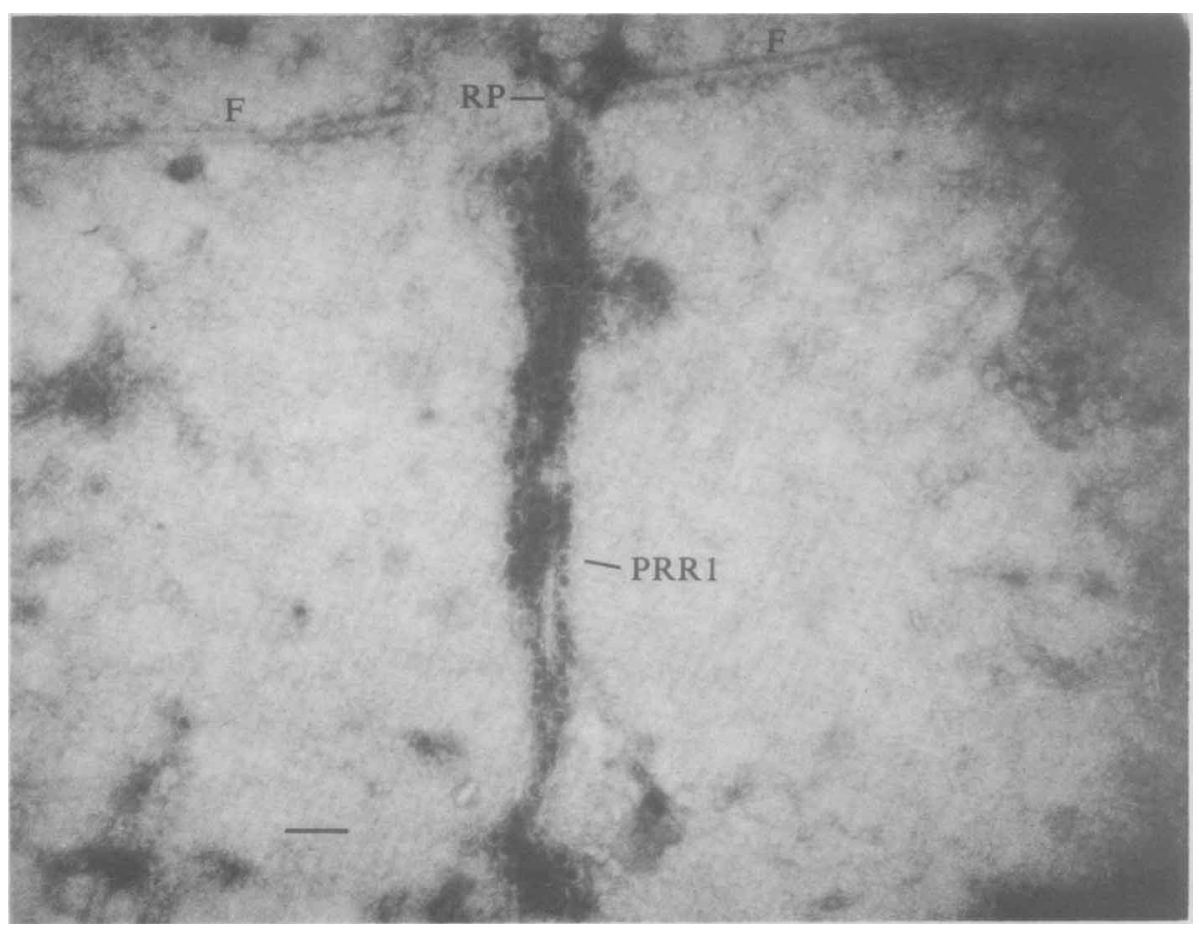

Fig. 2. Electron micrograph of phage PRR1 bound to a bundle of RP1-specified pili from E. coli CSH29R+. Note flagella (F) and RP1-specified pilus (RP). The bar marker represents $100 \mathrm{~nm}$.

Table 2. Phage PRR1 inactivation by shearates of several $R^{+}$and $R^{-}$strains

$\begin{array}{lrc}\text { Source of shearate } & \text { No. of plaques per plate* } & \text { Phage inactivat } \\ \text { PAO67 } & 112 \cdot 3 & 30 \\ \text { CSH29R }^{+} & 80 \cdot 2 & 50 \\ \text { WS48R }^{+} & 162 \cdot 1 & 0 \\ \text { CSH29 } & 157 \cdot 2 & 1 \cdot 6 \\ \text { WS48 } & 155 \cdot 1 & 2 \cdot 9 \\ \text { Blank control } & 159 \cdot 7 & 0\end{array}$

* Mean of 14 determinations.

Effect of anti-shearate antiserum on phage PRR 1 adsorption to whole cells. As described above, PAO67 and CSH29R ${ }^{+}$cells adsorbed phage PRR 1 while WS48R ${ }^{+}$did not. If RP1 pili are produced in $\mathrm{WS}_{4} \mathrm{R}^{+}$with modified phage attachment sites yet are unaltered antigenically, antibody produced against $\mathrm{WS} 48 \mathrm{R}^{+}$shearate should also react with RP1 pili produced in other $\mathrm{R}^{+}$strains. The effect of various anti-shearate antisera on phage adsorption by PAO67 and CSH29R ${ }^{+}$cells was therefore determined. Antiserum against WS48 shearate served as the negative control. In the presence of WS48 antiserum, PAO67 cells inactivated

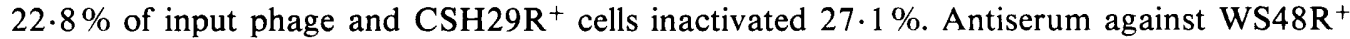
shearate inhibited phage adsorption by these two susceptible strains, to about $2 \%$ and $4 \%$ of input phage, respectively, suggesting the presence in the WS48 $\mathrm{R}^{+}$shearate of material that is antigenically similar to plasmid R P1-specified phage-adsorbing pili.

Phage inactivation by shearates in the presence of antiserum. The effects of the various anti-shearate antisera on phage inactivation by shearates was also determined. In the presence of blank or pre-immune serum, PAO67 shearate adsorbed about $17 \%$ of input phage PRR1 
and $\mathrm{CSH} 29 \mathrm{R}^{+}$shearate adsorbed about $45 \%$. (The difference in phage inactivation capacity between PAO67 shearate and $\mathrm{CSH}_{29 \mathrm{R}^{+}}$shearate is probably the result of CSH29R ${ }^{+}$ shearate containing more $\mathrm{R}$ pili than PAO67 shearate, due either to the method of culturing or to greater production of $\mathrm{R}$ pili by $\mathrm{CSH} 29 \mathrm{R}^{+}$.) Antiserum against $\mathrm{CSH} 29$ shearate had little or no effect on phage inactivation by either PAO67 shearate or $\mathrm{CSH}_{29} \mathrm{R}^{+}$shearate. However, when antisera against shearates from RP1-containing strains were used to treat the shearates, the phage inactivation capacity of the shearates was reduced. When PAO67 shearate was treated with anti-shearate antiserum against $\mathrm{CSH}_{2} 9 \mathrm{R}^{+}$, WS48R $\mathrm{R}^{+}$or PAO67, its phage inactivation capacity dropped to less than $5 \%$, and when $\mathrm{CSH} 29 \mathrm{R}^{+}$shearate was treated with anti-shearate antiserum against $\mathrm{CSH}_{2} 2 \mathrm{R}^{+}, \mathrm{WS}_{48 \mathrm{R}^{+}}$or $\mathrm{PAO} 67$, its phage inactivation capacity dropped to less than $30 \%$.

Effect of anti-shearate antisera on plasmid RP1 transfer. The effect of various antisera on plasmid transfer was determined using the RP1-containing strains PAO67, CSH29R ${ }^{+}$and $\mathrm{WS}_{48 \mathrm{R}^{+}}$as donors with $Y$. enterocolitica W277 as the recipient (Fig. 3). Antiserum against the shearate of one strain agglutinates the intact cells of that same strain as well as those of the isogenic $\mathrm{R}^{-}$strain. For example, in the WS48R $\mathrm{R}^{+} \times \mathrm{W} 277$ cross, WS48 $\mathrm{R}^{+}$whole cells were agglutinated by either anti-WS48 or anti-WS48R ${ }^{+}$shearate antiserum, thus the mating frequency was reduced because there were fewer WS48 ${ }^{+}$cells to serve as donors. Strain

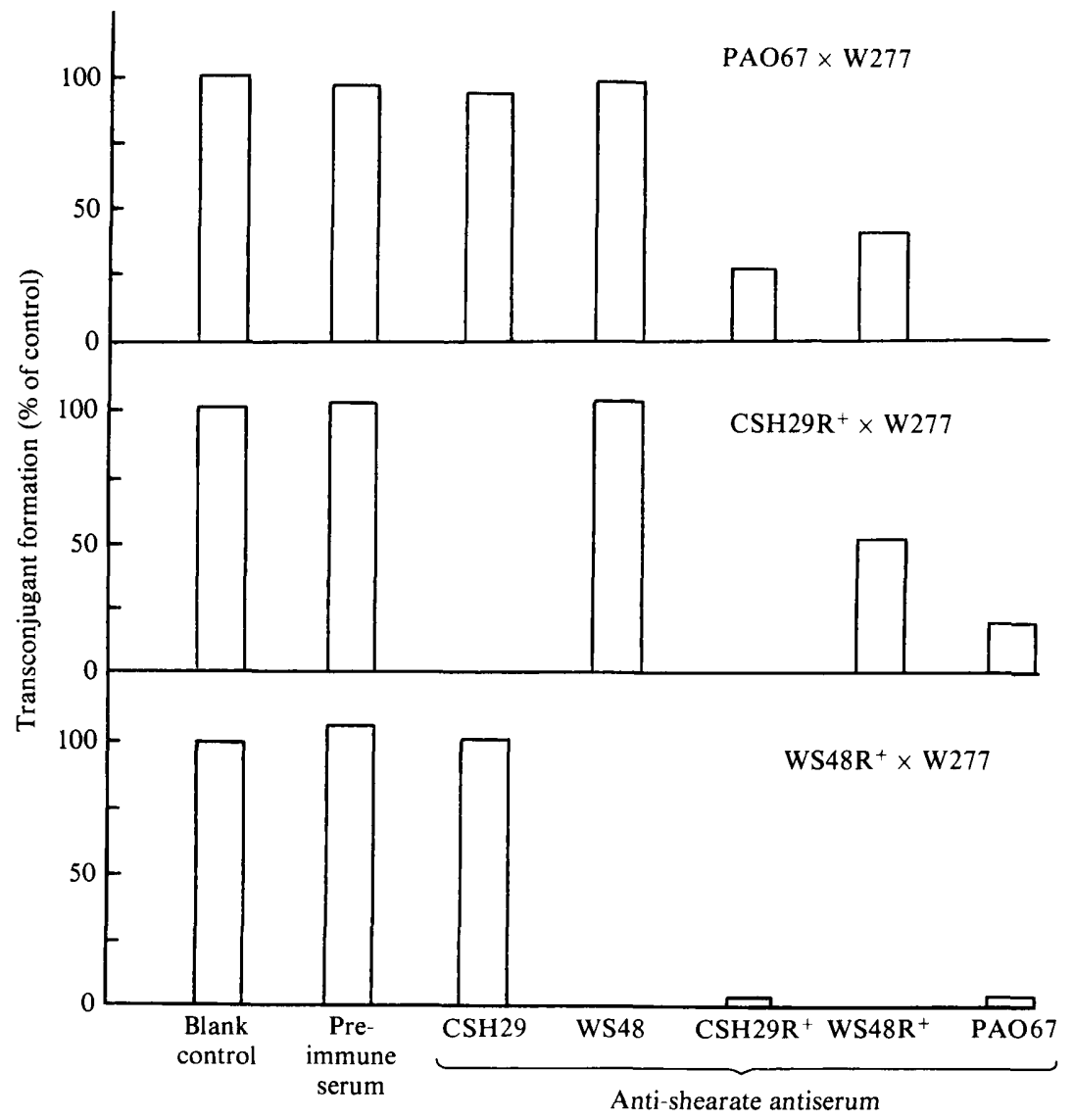

Fig. 3. Effect of anti-shearate antisera on plasmid RP1 transfer in three crosses. The numbers of transconjugants in the blank controls $\left(100 \%\right.$ transconjugants) were: PAO67 $\times$ W277, $2.60 \times 10^{2}$ c.f.u. per $10^{-1}$ dilution plate; $\mathrm{CSH}_{29 \mathrm{R}^{+}} \times \mathrm{W} 277,2.83 \times 10^{2}$ c.f.u. per $10^{-1}$ dilution plate; $\mathrm{WS}_{48 \mathrm{R}^{+}} \times \mathrm{W} 277$, $1.55 \times 10^{2}$ c.f.u. per $10^{0}$ plate. 
Table 3. Effect of intact and RNAase-treated phage PRRl on the viability of $R^{+}$and $R^{-}$ bacterial strains

The viable counts of the untreated controls $\left(100 \%\right.$ survival) were (c.f.u. $\mathrm{ml}^{-1}$ ): PAO67, $4.7 \times 10^{7}$; $\mathrm{W} 277,3.4 \times 10^{7} ; \mathrm{W} 277 \mathrm{R}^{+}, 2.3 \times 10^{7} ; \mathrm{WS}^{2} 8 \mathrm{R}^{+}, 2.8 \times 10^{8}$.

\begin{tabular}{lccc} 
& \multicolumn{3}{c}{ Viability (\% of control) } \\
\cline { 2 - 4 } Strain & 95.4 & PRR 1 only & PRR 1 + RNAase \\
PAO67 & 97.8 & 31 & $90 \cdot 4$ \\
W277 & 94.0 & 100 & $99 \cdot 2$ \\
W277R $^{+}$ & 99.6 & $6 \cdot 3$ & $81 \cdot 0$ \\
WS48R $^{+}$ & & 100 & 100
\end{tabular}

W277 was chosen as the recipient because it was not agglutinated by any of the antisera. Anti-CSH29 shearate antiserum and anti-WS48 shearate antiserum were used as negative controls. When PAO67 or CSH29R ${ }^{+}$was the donor, the mating frequency was reduced by at least $50 \%$ in the presence of $\mathrm{R}^{+}$shearate antisera. The effect of anti-shearate antisera on transconjugant formation was especially marked in the WS48 $\mathrm{R}^{+} \times \mathrm{W} 277$ cross: when donor WS48R ${ }^{+}$was treated with anti-CSH29R ${ }^{+}$shearate antiserum or anti-PAO67 shearate antiserum, transfer of the plasmid could not be detected.

Plasmid RP1 transfer in the presence of phage PRR1. The experiments described above showed that antiserum against $\mathrm{WS}_{4} 8 \mathrm{R}^{+}$shearate inhibits conjugation and phage PRR 1 inactivation by other $\mathrm{R}^{+}$strains, suggesting that $\mathrm{R} P 1$-specific conjugal pili as well as material that is antigenically similar to phage-binding pili is present in $\mathrm{WS}_{48} \mathrm{R}^{+}$shearates. Since WS $48 \mathrm{R}^{+}$can transfer RP1 but not adsorb phage PRR1, it was still unclear whether $(a)$ two different $\mathrm{RP} 1$-encoded pili were present on all $\mathrm{R}^{+}$strains, with the phage-binding pili being functionally but not antigenically modified in WS48 $\mathrm{R}^{+}$. or $(b)$ a single $\mathrm{R}$ pilus serving both functions was present in all $\mathrm{R}^{+}$strains, but was modified in WS48 $\mathrm{R}^{+}$so that it functioned only as the organelle of conjugation. If the first possibility were true, that is. if there are two kinds of $\mathrm{R}$ pili, one for conjugation and one for phage binding, then PAO67, harbouring plasmid RP1, should conjugate and transfer RP1 with relatively normal frequency even if the phage-binding pili were coated by inactivated phage.

RNA phage attachment to cell-associated $F$ pili is followed almost immediately by a loss of phage infectivity and the concomitant sensitization of the phage RNA to RNAase (Valentine \& Wedel, 1965: Danziger \& Paranchych, 1970). Thus, in the presence of RNAase, a phage-susceptible host should be protected from infection by some RNA phages. The results in Table 3 show that such is the case with phage PRR 1 for the $\mathrm{R}^{+}$strains used in this study. Strains PAO67 and W277R ${ }^{+}$, both susceptible to phage PRR1, were protected by RNAase A as compared with the controls. Strains WS48R ${ }^{+}$and W277. on the other hand, were not affected by any of the treatments.

The effect on transconjugant yields of phage PRR 1 treated with RNAase was also determined. In the PAO67 $\times$ W2 77 cross, when donor cells were incubated with phage PRR 1 plus RNAase, although phage infection was prevented, the mating frequency was nonetheless reduced to $25 \%$ of the control value (from 293 transconjugants to 73 transconjugants on the $10^{-1}$ dilution plates). In the WS48R ${ }^{+} \times \mathrm{W} 277$ cross, phage PRR 1 plus RNAase had no effect on the mating frequency.

Crosses of the same strains (PAO67 $\times$ W277 and WS48R ${ }^{+} \times$W277) which were exposed to phage PRR1 without RNAase were also performed. In both cases, transconjugant formation was reduced, as would be expected, since $\mathrm{W} 277 \mathrm{R}^{+}$is susceptible to the phage. These data show that when non-infectious phage PRR 1 binds to susceptible $\mathrm{R}^{+}$strains they no longer serve as donors. 


\section{DISCUSSION}

An alteration of plasmid RP1 pilus function in Caulobacter vibrioides $\mathrm{WS}_{48} \mathrm{R}^{+}$has been demonstrated in this study. Caulobacter $\mathrm{R}^{+}$strains express RP1-encoded transferability and antibiotic resistance markers, but they are insensitive to the RP1-dependent phage PRR 1. The physical integrity of RP1 in Caulobacter $\mathrm{R}^{+}$is implicit because when RP1 is transferred from Caulobacter $\mathrm{R}^{+}$to $E$. coli CHS29 or Y. enterocolitica W277, all the RP1-encoded markers are expressed in the transconjugants. Since both RP1 transfer and phage PRR 1 susceptibility involve pili, the $\mathrm{RP} 1$ pilus in Caulobacter $\mathrm{R}^{+}$must be different from that in other $\mathrm{R}^{+}$strains.

Gene transfer among Caulobacter species readily occurs (Jollick \& Schervish, 1972); however, pili of the $\mathrm{F}$ or $\mathrm{P}$ type are not seen. Caulobacter $\mathrm{R}^{-}$species produce only common pili. Evidence from this study indicates that $C$. vibrioides $\mathrm{WS} 48 \mathrm{R}^{+}$does not use pre-existing pili for RP1 transfer. The evidence is as follows: (1) WS48 $\mathrm{R}^{+}$produces RP1-specified pili as seen by electron microscopy; (2) antibody produced against WS48 shearates (containing common pili) does not inhibit RP1 transfer by other $\mathrm{R}^{+}$strains, while antibody against WS48 $\mathrm{R}^{+}$shearates (containing both common pili and RP1 pili) does, suggesting that an RP1-specific conjugal pilus is present in WS48 $R^{+}$shearates; (3) RP1 transfer in the WS48 $R^{+}$ $\times$ W277 cross was blocked by antibody produced against shearates of PAO67 or CSH29R ${ }^{+}$. If WS48 $\mathrm{R}^{+}$did use common pili for RP1 transfer, the inhibition of RP1 transfer effected by PAO67 or CSH29R ${ }^{+}$shearate antibody would not have occurred, since there is no cellular appendage in the PAO67 shearate or the $\mathrm{CSH} 29 \mathrm{R}^{+}$shearate which is antigenically similar to the Caulobacter common pilus.

Assay of phage PRR1 adsorption by whole cells and shearates indicated that PRR1 infection in $\mathrm{WS}_{48 \mathrm{R}^{+}}$was defective in the initial step, i.e. phage adsorption. These facts suggested the possibility that two RP1-specified pili, one for phage binding, the other for conjugation, may exist and that the phage-binding pilus is absent in WS48 $\mathrm{R}^{+}$. However, antiserum produced against $\mathrm{WS}_{4} \mathrm{R}^{+}$shearates inhibits the phage PRR 1 inactivation capacity of either whole cells or shearates of PAO67 or CSH29R $R^{+}$. This suggests that the phage-binding pilus is not absent from WS48 $\mathrm{R}^{+}$shearate. We may therefore conclude either (a) two different RP1-encoded pili are present on both WS48 $\mathrm{R}^{+}$and the other $\mathrm{R}^{+}$strains, and the conjugal pilus is functional in both but the phage-binding pilus is modified in WS48 $\mathrm{R}^{+}$, or (b) a single pilus which serves both functions is present in WS48 $\mathrm{R}^{+}$and the other $\mathrm{R}^{+}$strains, but is modified in the Caulobacter $\mathrm{R}^{+}$strains so that it functions only as the organelle of conjugation. Another possibility cannot be excluded at this point, that is, the possible cross-reactivity of the antibodies produced against the Caulobacter $\mathrm{R}^{+}$conjugal pilus to phage-binding pili in other $\mathrm{R}^{+}$strains. However, the inhibition of plasmid transfer by inactivated phage PRR1 shows that there is only one kind of RP1 pilus produced and that in WS48R $\mathrm{R}^{+}$the RP1-specified pilus serves only the conjugal function.

The basis of the functional modification of the RP1 pilus in Caulobacter has not been established. Several possible mechanisms can be invoked; however, our data do indicate that Caulobacter does not modify the pilus by any extracellular mechanism. We speculate that an intracellular function that modifies the pilin protein to produce the final extracellular structure is missing in Caulobacter. Compositional analysis of RP1-specified pili produced by Caulobacter $\mathrm{R}^{+}$and other $\mathrm{R}^{+}$strains is in progress.

\section{REFERENCES}

Adams, M. H. (1959). Bacteriophages, pp. 134-162. New York: Interscience Publishers.

Alexander, J. L. \& Jollick, J. D. (1977). Transfer and expression of Pseudomonas plasmid RP1 in Caulobacter. Journal of General Microbiology 99. 325-331.

Blair, J. E. \& Williams, R. E. O. (1961). Phage typing of staphylococci. Bulletin of the World
Health Organization 24, 771-784.

Danziger, R. E. \& Paranchych, W. (1970). Stages in phage R17 infection. III. Energy requirements for the F-pili mediated eclipse of viral infectivity. Virology 40, 554-572.

Ely, B. (1979). Transfer of drug resistance factors to the dimorphic bacterium Caulobacter crescentus. Genetics 91, 371-380. 
Jollick, J. D. \& Schervish, E. (1972). Genetic recombination in Caulobacter. Journal of General Microbiology 73, 403-407.

Jollick, J. D. \& Tran, T. Q. (1975). Polarity of gene transfer in Caulobacter. Journal of General Microbiology 91, 183-187.

Olsen, R. \& Shipley, P. (1973). Host range and properties of the Pseudomonas aeruginosa $\mathbf{R}$ factor R 1822. Journal of Bacteriology 113, 772-780.

Olsen, R. \& Thomas, D. D. (1973). Characteristics and purification of PRR1, an RNA phage specific for the broad host range Pseudomonas R1822 drug resistance plasmid. Journal of Virology 12, 15601567.

OUCHTERLONY, O. (1968). Handbook of Immunodiffusion and Immunoelectrophoresis. Ann Arbor, Michigan: Ann Arbor Science Publishers.

PoINDEXTER, J. (1974). Biological properties and classification of the Caulobacter group. Bacteriological Reviews 28, 231-295.

VAlentine, R. \& Wedel, H. (1965). The extracellular stages of RNA bacteriophage infection. Biochemical and Biophysical Research Communications 21, 106-117. 